\section{Plant Regeneration from Leaf-derived Callus Cultures of Primrose (Primula vulgaris)}

\author{
Sadiye Hayta \\ School of Biological Sciences, University of East Anglia, Norwich Research \\ Park, Norwich, NR4 7TJ, UK; and John Innes Centre, Norwich Research \\ Park, Norwich, NR4 7UH, UK
}

Mark A. Smedley

John Innes Centre, Norwich Research Park, Norwich, NR4 7UH, UK

Jinhong Li

School of Biological Sciences, University of East Anglia, Norwich Research Park, Norwich, NR4 7TJ, UK; and John Innes Centre, Norwich Research Park, Norwich, NR4 7UH, UK

Wendy A. Harwood

John Innes Centre, Norwich Research Park, Norwich, NR4 7UH, UK

Philip M. Gilmartin ${ }^{1}$

School of Biological Sciences, University of East Anglia, Norwich Research Park, Norwich, NR4 7TJ, UK; and John Innes Centre, Norwich Research Park, Norwich, NR4 7UH, UK

Additional index words. Primulaceae, micropropagation, shoot regeneration, thidiazuron, $\mathrm{AgNO}_{3}$

Abstract. Efficient micropropagation of Primula species is important both for fundamental scientific studies and commercial applications. Primula vulgaris (Huds), along with other Primulaceae species, exhibits floral heteromorphy with two distinct forms of hermaphroditic flower. Studies to identify genes that control heteromorphic flower development require propagation of floral mutants, and efficient regeneration is a key requirement for plant transformation. Several species, including $P$. vulgaris cultivars and $P$. Xpolyantha hybrids, are important horticultural crops in Europe, United States, and Japan and semidouble/double Primula varieties offer a high-end product. Vegetative propagation of sterile double forms, and as a means to increase numbers of inbred parent plants for $F_{1}$ seed production is, however, slow. Micropropagation offers the most efficient way of increasing these varieties quickly and efficiently. To date, most Primula micropropagation protocols require explant material derived from in vitro grown seedlings or use floral parts as donor material with seasonal limitations. Therefore, an effective and efficient protocol was developed for in vitro regeneration of $P$. vulgaris via indirect organogenesis from adult leaf-derived explants. Exposure of leaf explants of $P$. vulgaris to media containing synthetic cytokinin, thidiazuron (TDZ), and auxin [1-naphthylacetic acid (NAA) or 2,4-dichlorophenoxyacetic acid (2,4-D)] resulted in undifferentiated cell proliferation followed by differentiated growth as shoot organogenesis. Silver nitrate improved in vitro callus growth and increased shoot regeneration further, with up to $72 \%$ of explants producing shoots. Regenerated plants developed normally and produced normal fertile flowers within 7 months. The system was also successfully applied for the micropropagation of sterile double-flowered $P$. vulgaris 'Sue Jervis'. The protocol reported here enables propagation of $P$. vulgaris without seasonal limitation or destruction of valuable parent donor material. The protocol, with further development, has the potential to underpin development of a transformation system for Primula, which would be of value in studies on flower development and disease resistance in laboratory grown plants.

Several Primula species, including $P$. vulgaris cultivars and $P$. xpolyantha hybrids are important horticultural crops in Europe, United States, and Japan. Primula plants are produced mainly for autumn and early spring bedding and pot plant markets with different cultivars and $F_{1}$ hybrids developed for improved germination rate, uniform grower, Primula offers a good return for relatively low inputs; low growing temperatures and high plant densities at a time in the season when few other ornamental crops are available (Erwin, 1999; Karlsson, 2002).

Academically, and the reason for this study, $P$. vulgaris, along with many other species of the Primulaceae, provide important examples of heteromorphic flower development (Barrett and Shore, 2008). This breeding system, in which different individuals develop one of two forms of flower, known as pin and thrum, has attracted longterm attention, including that of Charles Darwin (Darwin, 1862). The underlying genes responsible for these pin and thrum flower forms are clustered within the $S$ locus. Ongoing studies endeavor to identify the genes within the $S$ locus that orchestrate floral heteromorphy (Li et al., 2011, 2015).

Many commercial breeders and amateur enthusiasts are involved in breeding, hybridizing, propagating, and cultivation of the numerous Primula species and their hybrids. Many new innovative named varieties are being produced in Europe, United States, and Japan (Karlsson, 2001). The attractive semidouble/double Primula varieties and named novel varieties, some of which date back to the 16th and 17th centuries (Gerard, 1597; Parkinson, 1629), offer a high-end product for the commercial grower, and an insight into the genes involved in floral development for the academic. However, these sterile double forms can only be propagated through vegetative means. Vegetative propagation may also be used to increase the population size of plants used as parents in $F_{1}$ seed production. Micropropagation techniques offer the fastest way of propagating these varieties.

The first report of Primula micropropagation (Coumans et al., 1979) described propagation of Primula obconica from inflorescence tips as explants. Subsequent micropropagation studies of Primula required explant material derived from in vitro grown seedlings of Primula cuneifolia var. hakusanensis, Primula scotica, Primula veris, Primula $\times$ pubescens Jacq, and Primula heterochroma (Benson et al., 2000; Hamidoghli et al., 2011; Morozowska and Wesolowska, 2004; Shimada et al., 1997; Takihira et al., 2007) or involved destruction of the parent plant in studies with P. vulgaris (Merkle and Götz, 1990). To date, there is only one reported micropropagation method published for $P$. vulgaris, which does not destroy the donor plants (Schween and Schwenkel, 2002). This method and its refinements (Schween and Schwenkel, 2003) regenerated plantlets from pedicle explants. Although reasonably efficient, the obligate requirement for floral material to initiate culture greatly limits this system. The limited amount of floral material produced per plant and the seasonal requirements for flower initiation further limit this system. In the present study, we report an efficient, robust, micropropagation system of $P$. vulgaris, which uses leaf material to initiate explant culture. We have successfully applied the system to micropropagate the commercially available double-flowered 
cultivar $P$. vulgaris Sue Jervis. Abundant donor material is readily available all yearround without seasonal limitation and the system is nondestructive of valuable plants. This technique also offers the potential for development of a plant transformation system for Primula species which would be of value in studies on flower development, color formation, and disease resistance in laboratory grown plants.

\section{Material and Methods}

Media. All media were prepared at double $(2 \times)$ the final required concentration, adjusted to $\mathrm{pH} 5.8$ and filter sterilized. Phytagel (catalog no. P8169; Sigma-Aldrich Co., St. Louis, MO), used as the gelling agent, was also prepared at double final required concentration, autoclaved, and stored at room temperature until required. To prepare the final medium, both double-concentration Phytagel and media components were heated to $60{ }^{\circ} \mathrm{C}$ in a water bath, then mixed together, and poured into $9-\mathrm{cm}-$ diameter petri dishes or Sterilin jars.

The basal medium consisted of Gamborg's B5 (Gamborg et al., 1968) macro salts with $966 \mathrm{mg} \cdot \mathrm{L}^{-1} \mathrm{KNO}_{3}$, half-strength Murashige and Skoog medium (MS; Murashige and Skoog, 1962) micro salts and full-strength MS vitamins, $30 \mathrm{~g} \cdot \mathrm{L}^{-1}$ maltose and was solidified with $1.75 \mathrm{~g} \cdot \mathrm{L}^{-1}$ Phytagel.

Primula callus induction (PCI) medium consisted of basal medium supplemented with $1.7 \mathrm{mg} \cdot \mathrm{L}^{-1}$ silver nitrate $\left(\mathrm{AgNO}_{3}\right)$, $4.0 \mathrm{mg} \cdot \mathrm{L}^{-1} 2,4-\mathrm{D}$, and $2.0 \mathrm{mg} \cdot \mathrm{L}^{-1} \mathrm{TDZ}$ or combinations of $2.0,3.0$, and $4.0 \mathrm{mg} \cdot \mathrm{L}^{-1} \mathrm{TDZ}$ and $0.3,0.5,1.0$, and $2.0 \mathrm{mg} \cdot \mathrm{L}^{-1} \mathrm{NAA}$. The medium was poured into $9-\mathrm{cm}$ petri dishes.

Primula shoot regeneration (PSR) medium consisted of basal medium supplemented with $4.0 \mathrm{mg} \cdot \mathrm{L}^{-1} 2,4-\mathrm{D}$ and $2.0 \mathrm{mg} \cdot \mathrm{L}^{-1} \mathrm{TDZ}$ or combinations $2.0,3.0$, and $4.0 \mathrm{mg} \cdot \mathrm{L}^{-1} \mathrm{TDZ}$ and $0.1,0.2,0.3$, and $0.5 \mathrm{mg} \cdot \mathrm{L}^{-1} \mathrm{NAA}$ with either $0.85,1.7$, or $3.4 \mathrm{mg} \cdot \mathrm{L}^{-1} \mathrm{AgNO}_{3}$. The medium was poured into $9-\mathrm{cm}$ petri dishes.

Primula rooting medium (PRM) consisted of woody plant medium (WPM) (Lloyd and McCown, 1981) basal salts with $2 \%$ sucrose, $0.5 \mathrm{mg} \cdot \mathrm{L}^{-1}$ indole-3-butyric acid (IBA), solidified with $1.75 \mathrm{~g} \cdot \mathrm{L}^{-1}$ Phytagel. About $25 \mathrm{~mL}$ medium was poured into $100-\mathrm{mL}$ sterile culture jars (Sterilin 185AM).

Received for publication 15 Feb. 2016. Accepted for publication 16 Mar. 2016.

We are grateful to the BBSRC for support via grant BB/H019278/2, Pam Wells for horticultural support, and the Gatsby Charitable Foundation for additional financial support. We also thank the University of East Anglia for support and the John Innes Centre for hosting PGs laboratory under the UEA-JIC Norwich Research Park collaboration. PG would like to thank Margaret Webster for discussions on Primula tissue culture before commencement of the work presented here.

${ }^{1}$ Corresponding author. E-mail: p.gilmartin@uea. ac.uk.

This is an open access article distributed under the CC BY-NC-ND license (http://creativecommons. org/licenses/by-nc-nd/4.0/).
Plant material and sterilization. P. vulgaris plants were used as the initial explant source for this study. Parent plants were grown in 1-L pots of peat-based multipurpose compost (MPC60; Erin Horticulture, Ireland) in a glasshouse at $16 \pm 1{ }^{\circ} \mathrm{C}$ day and night, relative humidity (RH) 60\% under natural light. Tender leaves $\approx 5 \mathrm{~cm}$ long, were thoroughly washed with cool running water for $1 \mathrm{~h}$. Under aseptic conditions, the leaves were surface sterilized with $70 \%$ ethanol (v/v) for $1 \mathrm{~min}$, followed by $6 \mathrm{~min}$ in $10 \%$ (v/v) sodium hypochlorite (Fluka 71696) with a drop of Tween 20 (P-9416; Sigma), and subsequently, rinsed three times with distilled-sterile water.

In vitro culture. The outer edges of the leaves were removed with a scalpel and discarded. The leaf material was cut transversely into $\approx 0.5-\mathrm{cm}^{2}$ sections containing major veins. Leaf sections were placed with abaxial surface in contact with the PCI medium. Three petri dishes per treatment with five explants per petri dish were cultured. The cultures were kept in a controlled culture cabinet at $18 \pm 1{ }^{\circ} \mathrm{C}$ in the dark for 4 weeks for callus initiation.

After two subcultures (4 weeks), the calli which had developed on PCI medium were transferred to PSR media. These were cultured under cool fluorescent lights $\left(100 \mu \mathrm{mol} \cdot \mathrm{m}^{-2} \cdot \mathrm{s}^{-1}\right)$ at $21 \pm 1^{\circ} \mathrm{C}$ with a $16-\mathrm{h}$ photoperiod. The cultures were subcultured four times onto fresh PSR media every 2 weeks for shoot regeneration.

Rooting. The adventitious shoots that developed on PSR media were isolated from the callus material when they had formed small rosettes of $\approx 1$ to $1.5 \mathrm{~cm}$ across consisting of three to five leaves. These rosettes were transferred individually to $100-\mathrm{mL}$ Sterilin jars containing PRM for further development and rooting.

Acclimatization. Well-developed regenerated plantlets were gently removed from the jars using long forceps and all tissue culture medium washed from the roots with cool running water. They were planted in the multipurpose compost in $5-\mathrm{cm}^{2}$ cells within propagation trays. Plants were covered with clear plastic propagator lids for $\approx 2$ weeks to maintain high humidity around them while they established. Plants were grown in a controlled environment room at $18 \pm 1{ }^{\circ} \mathrm{C}$ day $(16 \mathrm{~h})$ and $15 \pm 1{ }^{\circ} \mathrm{C}$ night temperatures, $75 \% \mathrm{RH}$ with $250 \mu \mathrm{mol} \cdot \mathrm{m}^{-2} \cdot \mathrm{s}^{-1}$ light intensity provided by metal halide lamps (HQI; OSRAM GmbH, Munich, Germany) supplemented with tungsten bulbs at 16-h photoperiod.

After a further 3-4 weeks, they were potted on into $15-\mathrm{cm}$-diameter pots. The plants were grown further until they established a good root system, visible through the drainage holes in the bottom of the pot; they were then transferred to 1-L pots. After the initial 6 weeks establishment, were fertilized with a weak $25 \mathrm{~g} \cdot \mathrm{L}^{-1}$ proprietary liquid feed (Phostrogen; Bayer Cropscience Ltd, UK) fortnightly to promote healthy growth.

Statistical analyses and experimental design. Experiments were arranged in a completely randomized design. Each treatment consisted of three replicates, 15 explants per replicate. Statistical analyses were carried out using Genstat software (version 16.1). Analysis of variance was performed for each experiment. The least significant difference test at $P=0.05$ was used for multiple mean comparisons.

\section{Results and Discussion}

Basal medium. During development of this protocol, leaf explants were initially cultured on a range of media, macro and micro salt and vitamin combinations including MS, B5, WPM, and Anderson's Rhododendron medium (Anderson, 1980) containing different carbon sources: sucrose, glucose, mannitol, and maltose (data not shown). None of these initial media gave callus proliferation, despite a range of plant growth regulators being used, with one exception. All but one of the media tested led to leaf browning and the release of phenolic compounds into the media was common. In medium containing B5 macro salts with $966 \mathrm{mg} \cdot \mathrm{L}^{-1} \mathrm{KNO}_{3}$, half-strength MS micro salts, and MS vitamins with $30 \mathrm{~g} \cdot \mathrm{L}^{-1}$ maltose, browning was limited and callus induction observed, therefore, this was chosen as the Primula basal medium (PBM).

$P$. vulgaris is a woodland species that has evolved in humus-rich, nutrient-poor soils (Jacquemyn et al., 2009). The majority of Primula species have relatively low nutrient requirements (Erwin, 1999; Karlsson, 2001). Primula is susceptible to ammonium toxicity and should be fertilized with a nitrate-based fertilizer (Erwin, 1999). The half-strength MS micro salts in our basal medium were favored by leaf-derived explants. MS medium contains two nitrogen salts, $\mathrm{NH}_{4} \mathrm{NO}_{3}(\approx 20 \mathrm{~mm})$ and $\mathrm{KNO}_{3}$ $(\approx 20 \mathrm{mM})$, which results in a nitrogen form ratio of $\mathrm{NH}_{4}$ to $\mathrm{NO}_{3}$ of $20: 40$ and gives a combined total of $\approx 60 \mathrm{~mm}$ for both nitrogen forms. This is considered to be a reasonably high nitrogen concentration, particularly for many woody species (Vinterhalter et al., 2007). For example, WPM contains about four times less nitrogen than MS medium. Gamborg et al. (1968) first demonstrated the significance of ammonium as a media component. Gamborg's B5 medium contains only $1 \mathrm{~mm}$ ammonium, 20 times lower than MS medium (Vinterhalter et al., 2007), making B5 macro salts suitable for the potentially ammonium toxicity susceptible Primula. The amount of $\mathrm{KNO}_{3}(966 \mathrm{mg})$ in PBM is $\approx 40 \%$ of standard Gamborg's B5 macro salts. The correct combination of salts with maltose was found to be essential for callus induction in leaf-derived Primula explants. After optimization of the correct media composition, the callus induction rate varied between $29 \%$ and $100 \%$ (Table 1). Callus induction started after $\approx 3$ weeks of culture.

Effects of $\mathrm{AgNO}_{3}$ supplementation. The inclusion of $\mathrm{AgNO}_{3}$ in the basal medium reduced the occurrence of tissue browning further. $\mathrm{AgNO}_{3}$ is widely used in plant tissue culture as a potent inhibitor of ethylene action (Beyer, 1976; Kumar et al., 2009); ethylene influences many aspects of growth and development throughout the plant's life cycle (Johnson and Ecker, 1998). In vitro studies have shown that ethylene can affect callus growth, organogenesis, shoot regeneration, and somatic embryogenesis often detrimentally (Kumar et al., 2009). By 
Table 1. Callus formation on Primula callus induction medium containing various concentration of thidiazuron (TDZ), 1-naphthylacetic acid (NAA), and 2,4-dichlorophenoxyacetic acid (2,4-D).

\begin{tabular}{|c|c|c|c|c|c|c|c|c|c|}
\hline \multirow[b]{2}{*}{$\mathrm{TDZ}\left(\mathrm{mg} \cdot \mathrm{L}^{-1}\right)$} & \multirow[b]{2}{*}{ NAA $\left(\mathrm{mg} \cdot \mathrm{L}^{-1}\right)$} & \multirow[b]{2}{*}{ 2,4-D $\left(\mathrm{mg} \cdot \mathrm{L}^{-1}\right)$} & \multirow[b]{2}{*}{ Callus color, structure } & \multicolumn{6}{|c|}{ Callus produced from explants } \\
\hline & & & & $\overline{\text { Amount }^{\mathrm{z}}}$ & Weeks $^{y}$ & $\%^{x}$ & No. ${ }^{\mathrm{w}}$ & $\mathrm{SD}^{\mathrm{v}}$ & Parity $^{\mathrm{u}}$ \\
\hline 2.0 & 0.0 & 0.0 & No callus, produced & - & - & - & - & - & - \\
\hline 3.0 & 0.3 & 0.0 & Green, compact & ++ & 4 & 100 & 45 & \pm 0.0 & (i) \\
\hline 3.0 & 0.5 & 0.0 & Green, compact & ++ & 4 & 38 & 17 & \pm 0.9 & (ii, iii) \\
\hline 3.0 & 1.0 & 0.0 & Green, compact & + & 5 & 47 & 21 & \pm 0.5 & (ii) \\
\hline
\end{tabular}

${ }^{\mathrm{z}}$ Amount of leaf explant surface that produced callus visually assessed after 8 weeks in culture: $+(<25 \%),++(25 \%$ to $50 \%),+++(50 \%$ to $75 \%),++++(>75 \%)$.

${ }^{y}$ Time in weeks for callus to appear.

${ }^{\mathrm{x}}$ The percentage of explants producing callus.

${ }^{\text {w} M e a n ~ n u m b e r ~(N o .) ~ o f ~ e x p l a n t s ~ p r o d u c i n g ~ c a l l u s ~ f r o m ~ t h r e e ~ e x p e r i m e n t s ~ w i t h ~ a ~ t o t a l ~ o f ~} 45$ explants per treatment $(n=45)$.

$\mathrm{v}_{\mathrm{SD}}$ from mean values of callus production.

"Parity of callus production between treatments based on a least significant difference test $(P<0.05)$, mean values that are not significantly different from each other are grouped as indicated by i, ii, or iii.

limiting ethylene production or its action within tissue cultures, greater control over growth and development can be achieved (Beyer, 1976; Wang et al., 2002). In Primula, the addition of $\mathrm{AgNO}_{3}$ to media reduced tissue browning and promoted healthy-looking callus with vigorous growth. Callus formation was seen to develop from the leaf edges which had been cut previously while preparing the explants for in vitro culture.

The inclusion of $\mathrm{AgNO}_{3}$ at $0.85 \mathrm{mg} \cdot \mathrm{L}^{-1}$ in PSR medium enhanced shoot regeneration from $27 \%$ to $44 \%$ (Table 2). Increasing the $\mathrm{AgNO}_{3}$ concentration from 0.85 to $3.4 \mathrm{mg} \cdot \mathrm{L}^{-1}$ further enhanced the rate of shoot regeneration from $44 \%$ to $72 \%$ (Table 2). As a potent inhibitor of ethylene, $\mathrm{AgNO}_{3}$ is also known to regulate the polyamine pool in plants. Polyamines are associated with several important cellular processes including cell division, morphogenesis, protein synthesis, DNA replication, and abiotic stress response (Kumar et al., 2009). The positive effects of $\mathrm{AgNO}_{3}$ on regeneration during clonal propagation of several economically important plant species have been reported (Fuentes et al., 2000; Naik and Chand, 2003; Uliaie et al., 2008). The inhibition of ethylene by $\mathrm{AgNO}_{3}$ and subsequent regulation of the polyamine pool could, in part, be the underlying process that stimulated the increase in shoot regeneration from $P$. vulgaris callus.

Optimization of plant growth regulators. The concentration of TDZ and auxin (NAA or 2,4-D) used, and the interaction between them significantly influenced the callus induction rate (Table 1). TDZ and auxin concentrations were also crucial for promoting dedifferentiation and regeneration within the tissue. The media with $4.0 \mathrm{mg} \cdot \mathrm{L}^{-1}$ 2,4-D, $2.0 \mathrm{mg} \cdot \mathrm{L}^{-1} \mathrm{TDZ}$, and $2.0 \mathrm{mg} \cdot \mathrm{L}^{-1} \mathrm{TDZ}$, $0.5 \mathrm{mg} \cdot \mathrm{L}^{-1} \mathrm{NAA}$ and $3.0 \mathrm{mg} \cdot \mathrm{L}^{-1} \mathrm{TDZ}$, $0.3 \mathrm{mg} \cdot \mathrm{L}^{-1} \mathrm{NAA}$ had the highest callus induction rates $(100 \%)$. Large green-cream compact callus formation was obtained in the media containing $4.0 \mathrm{mg} \cdot \mathrm{L}^{-1} 2,4-\mathrm{D}, 2.0 \mathrm{mg} \cdot \mathrm{L}^{-1} \mathrm{TDZ}$ (Fig. 1A). While in the medium containing $2.0 \mathrm{mg} \cdot \mathrm{L}^{-1} \mathrm{TDZ}$ and $0.5 \mathrm{mg} \cdot \mathrm{L}^{-1} \mathrm{NAA}$, compact smaller callus structures with some red anthocyanin pigmentation were seen (Fig. 1B). Anthocyanin production in vitro is usually associated with stress (Chalker-Scott, 1999). The

Table 2. Effect of different concentrations of $\mathrm{AgNO}_{3}$ on shoot regeneration from Primula vulgaris calli on Primula shoot regeneration medium.

\begin{tabular}{|c|c|c|c|c|c|}
\hline \multirow{2}{*}{\multicolumn{2}{|c|}{$\mathrm{AgNO}_{3}$}} & \multicolumn{4}{|c|}{ Shoot regeneration from callus tissue produced shoots ${ }^{2}$} \\
\hline & & \multicolumn{4}{|c|}{ No. of calli that produced shoots ${ }^{y} \pm S D$} \\
\hline$\mu_{\mathrm{M}}$ & $\mathrm{mg} \cdot \mathrm{L}^{-1}$ & $\%^{z}$ & No. ${ }^{y}$ & $\mathrm{SD}^{\mathrm{x}}$ & Parity $^{\mathrm{w}}$ \\
\hline 0 & 0 & 27 & 12 & \pm 0.8 & - \\
\hline 5 & 0.85 & 44 & 20 & \pm 0.5 & - \\
\hline 10 & 1.7 & 62 & 28 & \pm 0.9 & (i) \\
\hline 20 & 3.4 & 72 & 32 & \pm 0.5 & (i) \\
\hline
\end{tabular}

Calli were produced on Primula callus induction medium supplemented with $2.0 \mathrm{mg} \cdot \mathrm{L}^{-1}$ thidiazuron (TDZ) +4.0 and $1.7 \mathrm{mg} \cdot \mathrm{L}^{-1} \mathrm{AgNO}_{3}$ for 4 weeks before transferring to Primula shoot regeneration medium supplemented with $3.0 \mathrm{mg} \cdot \mathrm{L}^{-1} \mathrm{TDZ}+0.3 \mathrm{mg} \cdot \mathrm{L}^{-1}$ 1-naphthylacetic acid (NAA) with different $\mathrm{AgNO}_{3}$ concentrations.

${ }^{2}$ The percentage of calli producing shoots.

${ }^{y}$ Mean number (No.) of calli producing shoots from three experiments with a total of 45 calli per treatment $(n=45)$. ${ }^{\mathrm{x}} \mathrm{SD}$ from mean values of shoot production.

wParity of shoot production between treatments based on a least significant difference test $(P<0.05)$, mean values that are not significantly different from each other are grouped as indicated by $i$.

combination of $3.0 \mathrm{mg} \cdot \mathrm{L}^{-1} \mathrm{TDZ}$ and $0.3 \mathrm{mg} \cdot \mathrm{L}^{-1}$ NAA within the medium produced smaller green-compact callus structures (Fig. 1C). The callus induction of explants on a medium containing $1 \mathrm{mg} \cdot \mathrm{L}^{-1} \mathrm{NAA}$ or more was significantly reduced in comparison with media with either 0.5 or $0.3 \mathrm{mg} \cdot \mathrm{L}^{-1} \mathrm{NAA}(P<0.001)$ with fewer explants responding. However, medium with TDZ alone was detrimental to the plant material and failed to initiate callus (Table 1). Chemically, TDZ is completely different from other commonly used auxins and cytokinins, but has been shown to exhibit both auxin and cytokinin like affects due to its ability to modulate endogenous growth regulators (Guo et al., 2011; Murthy et al., 1995; Thomas and Puthur, 2004). After 6 to 9 weeks in culture, numerous shoots differentiated from the calli (Fig. 1D and E).

Regeneration occurred through the initiation of shoot primordia (Fig. 1F) and over a 2to 3-week period green shoots started to emerge (Fig. 1G), followed by leaf expansion (Fig. 1H). The regeneration was identified as adventitious shoot regeneration since the shoots were connected to callus cells by vascular tissue formation and were of a unipolar structure (Fig. 1F and $\mathrm{G}$ ), sometimes referred to as vegetative primordium (Nunes et al., 2013). The shoot regeneration rate for $P$. vulgaris varied between $26.7 \%$ and $66.7 \%$ (Table 3 ). The greatest shoot regeneration rate $(66.7 \%)$ was seen in the medium supplemented with $3.0 \mathrm{mg} \cdot \mathrm{L}^{-1} \mathrm{TDZ}$ and $0.3 \mathrm{mg} \cdot \mathrm{L}^{-1} \mathrm{NAA}$. TDZ played a critical role in promoting shoot differentiation from Primula callus. It has been shown to stimulate adventitious shoot regeneration in a large number of plant species such as Hydrangea, Sugarcane, Strawberry, and Dendrocalamus strictus (GalloMeagher et al., 2000; Haddadi et al., 2013; Lata et al., 2013; Ledbetter and Preece, 2004).

Rooting. It is clear that there is a strong relationship between salt combination and $\mathrm{TDZ}$, auxin, and $\mathrm{AgNO}_{3}$ present in the culture media used for $P$. vulgaris. To develop an efficient in vitro regeneration system, effective growth regulators with an appropriate mineral salt medium capable of inducing a high level of organogenesis are necessary. Previous reported studies found that the effect of growth regulators can be strongly modified by the medium on which the culture is grown (McCown and Sellmer, 1987). The adventitious shoots were transferred to WPM medium containing $0.5 \mathrm{mg} \cdot \mathrm{L}^{-1}$ IBA to root. Root primordia were seen to begin to develop after 10-15 d (Fig. 2). Several Primula species (P. cuneifolia, Primula malacoides, and $P$. obconica) have been reported to root on various phytohormone free media (Mizuhiro et al., 2001; Shimada et al., 1997). However, the inclusion of IBA appeared to stimulate root primordia development, which is in agreement with previous reports (Hamidoghli et al., 2011; Jia et al., 2014; Schween and Schwenkel, 2003). A subset of 20 P. vulgaris 

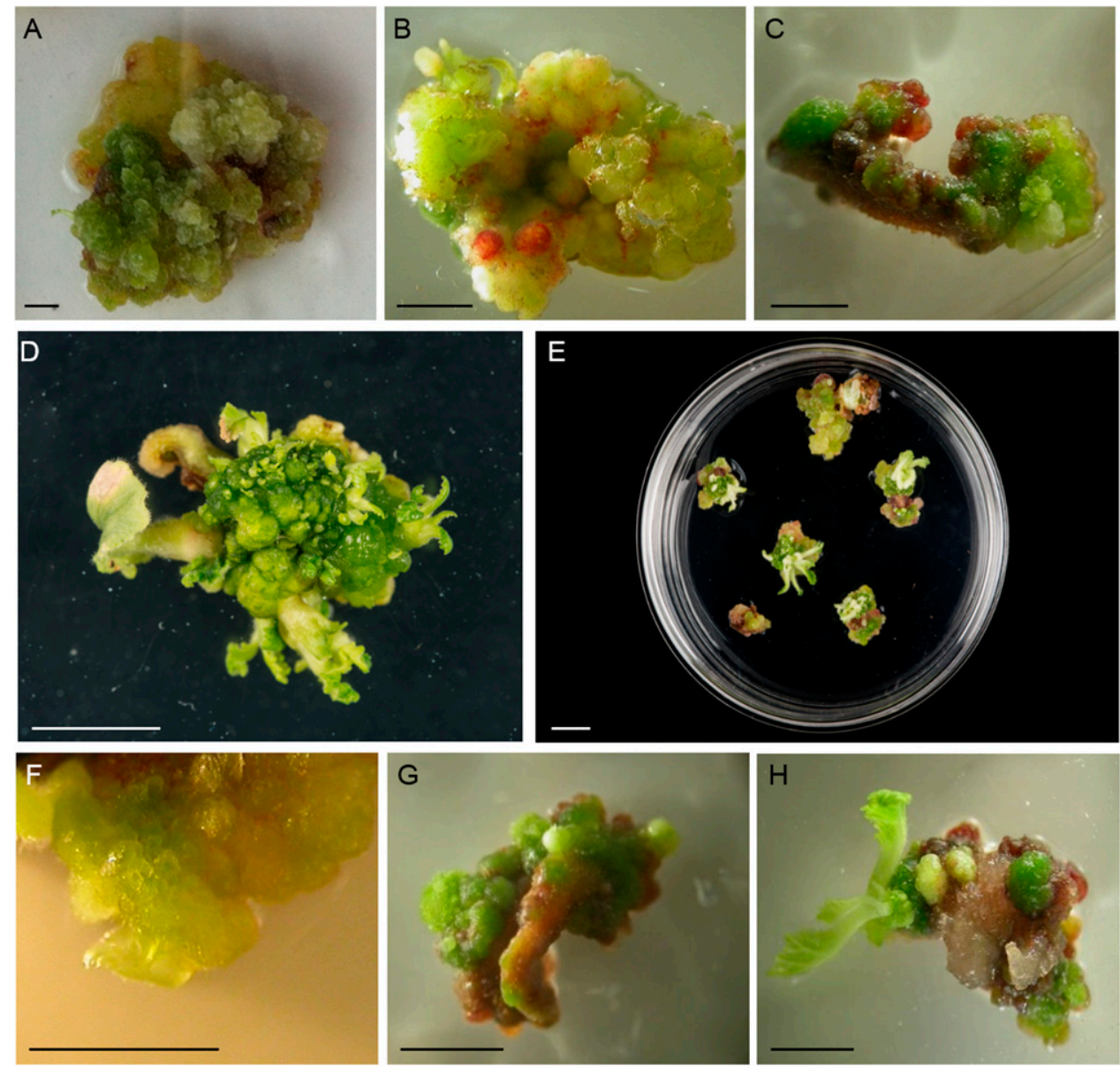

Fig. 1. Callus development, adventitious shoot development, and shoot development on Primula callus induction (PCI) medium and Primula shoot regeneration (PSR) medium with different plant growth regulators. (A) Large green-cream callus formation on PCI medium with $4.0 \mathrm{mg} \cdot \mathrm{L}^{-1}$ 2,4-dichlorophenoxyacetic acid (2,4-D) and $2.0 \mathrm{mg} \cdot \mathrm{L}^{-1}$ thidiazuron (TDZ). (B) Small compact callus with anthocyanin pigmentation on PCI medium with $2.0 \mathrm{mg} \cdot \mathrm{L}^{-1} \mathrm{TDZ}$ and $0.5 \mathrm{mg} \cdot \mathrm{L}^{-1} 1$-naphthylacetic acid (NAA). (C) Small green compact callus on PCI medium with $3.0 \mathrm{mg} \cdot \mathrm{L}^{-1} \mathrm{TDZ}$ and $0.3 \mathrm{mg} \cdot \mathrm{L}^{-1} \mathrm{NAA}$. (D and E) Callus induced from leaf segments on PCI medium supplemented with $4.0 \mathrm{mg} \cdot \mathrm{L}^{-1}$ 2,4-D, and $2.0 \mathrm{mg} \cdot \mathrm{L}^{-1} \mathrm{TDZ}$ for 4 weeks followed by 3 weeks on PSR medium $3.0 \mathrm{mg} \cdot \mathrm{L}^{-1} \mathrm{TDZ}$ and $0.3 \mathrm{mg} \cdot \mathrm{L}^{-1} \mathrm{NAA}$. Scale bar $=1 \mathrm{~cm}$. (F) Shoot primordium as a unipolar structure. (G) Shoot differentiation from callus tissue. (H) Shoot development with vascular connections to callus tissue.

Table 3. Effect of different concentrations of thidiazuron (TDZ), 1-naphthylacetic acid (NAA), and 2,4-dichlorophenoxyacetic acid (2,4-D) on shoot regeneration from Primula vulgaris calli on Primula shoot regeneration (PSR) medium.

\begin{tabular}{|c|c|c|c|c|c|c|c|}
\hline \multirow[b]{2}{*}{$\mathrm{TDZ}\left(\mathrm{mg} \cdot \mathrm{L}^{-1}\right)$} & \multirow[b]{2}{*}{ NAA $\left(\mathrm{mg} \cdot \mathrm{L}^{-1}\right)$} & \multirow[b]{2}{*}{ 2,4-D $\left(\mathrm{mg} \cdot \mathrm{L}^{-1}\right)$} & \multicolumn{5}{|c|}{ Shoot regeneration from callus tissue } \\
\hline & & & Weeks $^{2}$ & $\%^{y}$ & No. $^{x}$ & $\mathrm{SD}^{\mathrm{w}}$ & Parity $^{\mathrm{v}}$ \\
\hline 2.0 & 0 & 4.0 & 5 & 58 & 26 & \pm 1.9 & (i, ii) \\
\hline 2.0 & 0.5 & 0 & 4 & 60 & 27 & \pm 1.4 & $(\mathrm{i}, \mathrm{ii})$ \\
\hline 3.0 & 0.1 & 0 & 4 & 27 & 12 & \pm 1.4 & (iii) \\
\hline 3.0 & 0.3 & 0 & 2 & 67 & 30 & \pm 1.6 & (i) \\
\hline 3.0 & 0.5 & 0 & 3 & 31 & 14 & \pm 1.3 & (iii) \\
\hline 0.04 & 0.2 & 0 & 3 & 44 & 20 & \pm 1.2 & (ii, iii) \\
\hline
\end{tabular}

Calli were produced on Primula callus induction medium supplemented with $2.0 \mathrm{mg} \cdot \mathrm{L}^{-1} \mathrm{TDZ}+4.0$ and $1.7 \mathrm{mg} \cdot \mathrm{L}^{-1} \mathrm{AgNO}_{3}$ for 4 weeks before transferring to PSR medium containing $1.7 \mathrm{mg} \cdot \mathrm{L}^{-1} \mathrm{AgNO}_{3}$

${ }^{2}$ Time in weeks for shoot production.

y The percentage of calli producing shoots.

${ }^{x}$ Mean number (No.) of calli producing shoots from three experiments with a total of 45 calli per treatment $(n=45)$. ${ }^{\mathrm{w}} \mathrm{SD}$ from mean values of shoot production.

vParity of shoot production between treatments based on a least significant difference test $(P<0.05)$, mean values that are not significantly different from each other are grouped as indicated by i, ii, or iii.

plantlets transferred to soil were successfully acclimatized and adapted to conditions within the controlled environment room.

The optimized protocol was then tested on the sterile double-flowered $P$. vulgaris 'Sue Jervis'. A $25 \%$ regeneration rate was recorded for $P$. vulgaris 'Sue Jervis' when cultured on PCI medium supplemented with $4.0 \mathrm{mg} \cdot \mathrm{L}^{-1}$
2,4-D, $2.0 \mathrm{mg} \cdot \mathrm{L}^{-1} \mathrm{TDZ}$ for 4 weeks, followed by a further 8 weeks on PSR medium supplemented $3.0 \mathrm{mg} \cdot \mathrm{L}^{-1} \mathrm{TDZ}, 0.3 \mathrm{mg} \cdot \mathrm{L}^{-1} \mathrm{NAA}$, and $3.4 \mathrm{mg} \cdot \mathrm{L}^{-1} \mathrm{AgNO}_{3}$. The isolation and rooting of plantlets on WPM began after 5 weeks on PSR medium. A subset of three $P$. vulgaris 'Sue Jervis' plantlets were transferred to soil and successfully acclimatized.

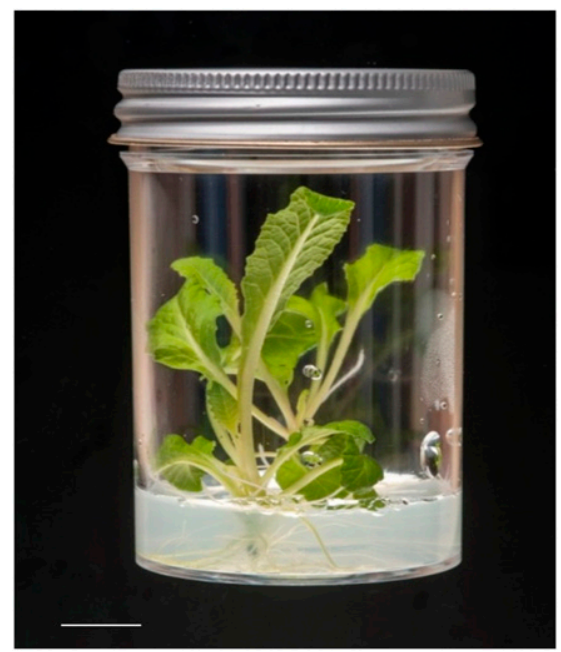

Fig. 2. Regeneration and rooting of Primula vulgaris plantlets. Plantlet after 4 weeks growth on a phytagel woody plant medium with $0.5 \mathrm{mg} \cdot \mathrm{L}^{-1}$ indole-3-butyric acid. Scale bar $=1 \mathrm{~cm}$.

The established plants developed normally and produced normal flowers within 7 months from the start of the tissue culture process 

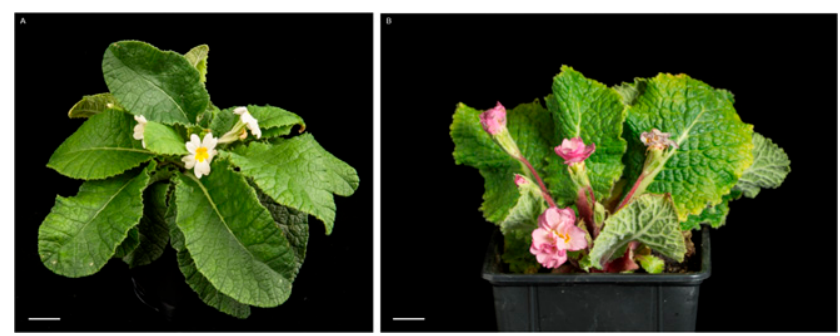

Fig. 3. Flowering Primula vulgaris (Huds.) and P. vulgaris 'Sue Jervis' plants after tissue culture. (A) Mature fertile P. vulgaris (Huds.) plant derived from in vitro culture after 12 weeks in soil. (B) $P$. vulgaris 'Sue Jervis' after 16 weeks in soil. Scale bars $=2 \mathrm{~cm}$.

(Fig. 3A and B). The P. vulgaris plants set seed after cross pollination between pin and thrum flowers. No evidence of morphological variation has been seen in regenerated plants.

\section{Conclusion}

In summary, we have developed an in vitro regeneration system for $P$. vulgaris plants, which uses leaves as its starting material, and have also applied the system for the propagation of the sterile doubleflowered $P$. vulgaris 'Sue Jervis'. The system is not only nondestructive to valuable parent plants, but also free from the seasonal limitations of using floral tissue. The system offers a robust method that has the potential to enable breeding companies to propagate new elite cultivars quickly and efficiently. It also offers the foundation for a plant transformation system to aid fundamental research into important traits in Primula species.

\section{Literature Cited}

Anderson, W.C. 1980. Tissue culture propagation of red and black raspberries, Rubus idaeus and R. occidentalis. Acta Hort. 112:13-20.

Barrett, S.C.H. and J.S. Shore. 2008. New insights on heterostyly: Comparative biology, ecology and genetics, p. 3-32. In: V.E. Franklin-Tong (ed.). Self-incompatibility in flowering plants. Springer-Verlag, Berlin Heidelberg, Germany.

Benson, E.E., J.E. Danaher, I.M. Pimbley, C.T Anderson, J.E. Wake, S. Daley, and L.K. Adams. 2000. In vitro micropropagation of Primula scotica: A rare Scottish plant. Biodivers. Conserv. 9:711-726.

Beyer, E.M. 1976. Potent inhibitor of ethylene action in plants. Plant Physiol. 58:268-271.

Chalker-Scott, L. 1999. Environmental significance of anthocyanins in plant stress responses. Photochem. Photobiol. 70:1-9.

Coumans, M., M.F. Coumans-Gilles, J. Delhez, and T. Gaspar. 1979. Mass propagation of Primula obconica cultivar Fleur de Pommier. Acta Hort. (Wageningen) 91:287-294.

Darwin, C.R. 1862. On the two forms or dimorphic condition in the species of Primula, and on their remarkable sexual relations. J. Linn. Soc. Bot. 6:77-96.

Erwin, J.E. 1999. Primula production. Minnesota Commercial Flower Growers Assoc. Bul. 48:1-8.

Federal Ministry of Food and Agriculture. 2014. Horticulture in Germany - Facts and Figures, Bonn, Germany. 28 Apr. 2016. <http://www.bmel. de/SharedDocs/Downloads/EN/Publications/ HorticultureGermany-Brochure.html>.

Fuentes, S.R.L., M.B.P. Calheiros, J. Manetti, and L.G.E. Vieira. 2000. The effects of silver nitrate and different carbohydrate sources on somatic embryogenesis in Coffea canephora. Plant Cell Tissue Organ Cult. 60:5-13.

Gallo-Meagher, M., R.G. English, and A. Abouzid. 2000. Thidiazuron stimulates shoot regeneration of sugarcane embryogenic callus. In Vitro Cell. Dev. Biol. Plant 36:37-40.

Gamborg, O.L., R.A. Miller, and K. Ojima. 1968. Nutrient requirements of suspension cultures of soybean root cells. Exp. Cell Res. 50:151-158.

Gerard, J. 1597. The herball or generall historie of plantes. John Norton, London, UK.

Guo, B., B.H. Abbasi, A. Zeb, L.L. Xu, and Y.H Wei. 2011. Thidiazuron: A multi-dimensional plant growth regulator. Afr. J. Biotechnol. 10: 8984-9000.

Haddadi, F., M. Abd Aziz, H. Kamaladini, and S.A. Rayanfar. 2013. Thidiazuron- and zeatin-induced high-frequency shoot regeneration from leaf and shoot-tip explants of strawberry. HortTechnology 23:276-281.

Hamidoghli, Y., A.R.N. Sharaf, and H. Zakizadeh 2011. Organogenesis from seedling derived leaf explants of primrose (Primula heterochroma Stapf.) as a scarce Iranian plant. Austral. J. Crop Sci. 5:391-395.

Jacquemyn, H., P. Endels, R. Brys, M. Hermy, and S.R.J. Woodell. 2009. Biological flora of the British Isles: Primula vulgaris Huds. (P. acaulis (L.) Hill). J. Ecol. 97:812-833

Jia, Y., Q.-X. Zhang, H.-T. Pan, S.-Q. Wang, Q.-L. Liu, and L.-X. Sun. 2014. Callus induction and haploid plant regeneration from baby primrose (Primula forbesii Franch.) anther culture. Sci. Hort. 176:273-281.

Johnson, P.R. and J.R. Ecker. 1998. The ethylene gas signal transduction pathway: A molecular perspective. Annu. Rev. Genet. 32:227-254.

Karlsson, M.G. 2001. Primula culture and production. HortTechnology 11:627-635.

Karlsson, M.G. 2002. Primula, an all-time favorite Greenhouse Product News. 34-43.

Kumar, V., G. Parvatam, and G.A. Ravishankar. 2009. $\mathrm{AgNO}_{3}$ - a potential regulator of ethylene activity and plant growth modulator. Electron. J. Biotechnol. 2:12.

Lata, H., S. Chandra, Y.H. Wang, V. Raman, and I.A. Khan. 2013. TDZ-induced high frequency plant regeneration through direct shoot organogenesis in Stevia rebaudiana Bertoni: An important medicinal plant and a natural sweetener. Amer. J. Bot. 4:117-128.

Ledbetter, D.I. and J.E. Preece. 2004. Thidiazuron stimulates adventitious shoot production from Hydrangea quercifolia Bartr. leaf explants. Sci. Hort. 101:121-126.

Li, J., M.A. Webster, M.C. Smith, and P.M Gilmartin. 2011. Floral heteromorphy in Primula vulgaris: Progress towards isolation and characterization of the S locus. Ann. Bot. 108:715-726.

Li, J., M.A. Webster, J. Wright, J. Cocker, M.C. Smith, F. Badakshi, P. Heslop-Harrison, and P.M. Gilmartin. 2015. Integration of genetic and physical maps of the Primula vulgaris $S$ locus and localization by chromosome in situ hybridization. New Phytol. 208:137-148.

Lloyd, G. and B. McCown. 1981. Commerciallyfeasible micropropagation of mountain laurel, Kalmia latifolia, by use of shoot-tip culture. Combined Proceedings, International Plant Propagators' Society 30:421-427.

McCown, B.H. and J.C. Sellmer. 1987. General media and vessels suitable for woody plant culture, p. 4-16. In: J.M. Bonga and D.J. Durza (eds.). Cell and tissue culture in forestry. Martinus Nijhoff Publishing, Dordrecht, The Netherlands.

Merkle, S. and E.M. Götz. 1990. Micropropagation of inbred lines of Primula acaulis for breeding purposes, p. 116. Abstracts of 7th Congress Plant Tissue Cell Cultures. June 24-29, Amsterdam, The Netherlands.

Mizuhiro, M., Y. Kenichi, K. Ito, S. Kadowaki, H. Ohashi, and M. Mii. 2001. Plant regeneration from cell suspension-derived protoplasts of Primula malacoides and Primula obconica. Plant Sci. 160:1221-1228.

Morozowska, M. and M. Wesolowska. 2004. In vitro clonal propagation of Primula veris $\mathrm{L}$. and preliminary phytochemical analysis. Acta Biol. Cracov. Ser. Bot. 46:169-175.

Murashige, T. and F. Skoog. 1962. A revised medium for rapid growth and bioassays with tobacco tissue cultures. Physiol. Plant. 15:473-497.

Murthy, B.N.S., S.J. Murch, and P.K. Saxena. 1995. Thidiazuron-induced somatic embryogenesis in intact seedlings of peanut (Arachis hypogaea): Endogenous growth-regulator levels and significance of cotyledons. Physiol. Plant. 94:268-276.

Naik, S.K. and P.K. Chand. 2003. Silver nitrate and aminoethoxyvinylglycine promote in vitro adventitious shoot regeneration of pomegranate (Punica granatum L.). Austral. J. Plant Physiol. 160:423-430

Nunes, C.F., D.N.D. Santos, M. Pasqual, T.C.T. Valente, A.C.L.d. Oliveira, E. Alves, and T.A. Setotaw. 2013. Morphogenesis and regeneration of adventitious shoots in Jatropha curcas L. Austral. J. Crop Sci. 7:1511-1519.

Parkinson, J. 1629. Paradisus in sole paradisus terrestris. Humfrey Lownes and Robert Young, London, UK.

Schween, G. and H.G. Schwenkel. 2002. In vitro regeneration in Primula ssp via organogenesis. Plant Cell Rpt. 20:1006-1010.

Schween, G. and H.G. Schwenkel. 2003. Effect of genotype on callus induction, shoot regeneration, and phenotypic stability of regenerated plants in the greenhouse of Primula ssp. Plant Cell Tissue Organ Cult. 72:53-61.

Shimada, T., T. Matsushita, and M. Otani. 1997. Plant regeneration from leaf explants of Primula cuneifolia var. hakusanensis, "Hakusankozakura". Plant Biotechnol. 14:47-50.

Takihira, M., M. Otani, S. Tsuchiya, and T. Shimada. 2007. Plant regeneration from leaf explants of auricula cultivars (Primula $\times$ pubescens Jacq.) Plant Biotechnol. 24:425-427.

Thomas, T.D. and J.T. Puthur. 2004. Thidiazuron induced high frequency shoot organogenesis in callus from Kigelia pinnata L. Bot. Bul. Acad. Sin. 45:307-313.

Uliaie, E.D., M. Farsi, B. Ghreyazie, and J. Imani. 2008. Effects of genotype and $\mathrm{AgNO}_{3}$ on shoot regeneration in winter cultivars of rapeseed (Brassica napus). Pak. J. Biol. Sci. 11:2040-2043.

Vinterhalter, B., S. Ninković, S. ZdravkovićKorać, A. Subotić, and D. Vinterhalter. 2007. Effect of nitrogen salts on the growth of Ceratonia siliqua L. shoot cultures. Arch. Biol. Sci. Belgrade 59(3):217-222.

Wang, K.L.C., H. Li, and J.R. Ecker. 2002. Ethylene biosynthesis and signaling networks. Plant Cell 14:S131-S151. 